Liberty of the Imagination 
This page intentionally left blank 


\title{
LIBERTY OF THE IMAGINATION
}

Aesthetic Theory, Literary Form, and Politics in the Early United States

\section{EDWARD CAHILL}

\author{
$\overline{\text { PENN }}$ \\ UNIVERSITY OF PENNSYLVANIA PRESS \\ PHIL A DEL PHIA
}


Copyright (c) 2012 University of Pennsylvania Press

All rights reserved. Except for brief quotations used for purposes of review or scholarly citation, none of this book may be reproduced in any form by any means without written permission from the publisher.

\author{
Published by \\ University of Pennsylvania Press \\ Philadelphia, Pennsylvania 19104-4112 \\ www.upenn.edu/pennpress \\ Printed in the United States of America \\ on acid-free paper \\ $\begin{array}{llllllllll}2 & 4 & 6 & 8 & 10 & 9 & 7 & 5 & 31\end{array}$
}

A Cataloging-in-Publication record is available from the Library of Congress ISBN 978-0-8122-4412-O 